\title{
TEACHING OF ENGLISH-SPEAKING SKILL BY GOVERNMENT SECONDARY SCHOOL ENGLISH TEACHERS OF QUETTA CITY
}

\section{Rahila Khan}

M. Phil Scholar, Department of English,

Sardar Bahadur Khan Women's University, Balochistan,

Pakistan

Email: rahilakhanmarri@gmail.com

\section{Zainab Akram}

Assistant Professor, Department of English,

Sardar Bahadur Khan Women's University, Balochistan,

Pakistan

\section{Sadia Suleman Khan}

Assistant Professor, Department of Education, Sardar Bahadur Khan Women's University, Balochistan,

Pakistan

\begin{abstract}
Speech is an important language skill used for communicating. It is the creative oral language skill that allows one to produce a logical spoken statement in order to express oneself meaningfully. For an effective communication, teaching of speaking skill at schools is of great importance. It is found that in Pakistan, speaking skill is not effectively taught at Government Secondary Schools. The objective of this study was to investigate the perceptions of Government Secondary School English teachers about the challenges they face in teaching English speaking skill to their students. Communicative competence presented by Dell Hymes in the 1960s, provided the theoretical framework for this study. The participants of this study were 100 Government Secondary School English teachers of Quetta city, out of whom 50 were male and 50 females. Data was collected using five items Likert scale questionnaire. Data was analyzed using SPSS. The findings revealed that the majority of English teachers spoke in both English and Urdu in their English class. It was also found that the teachers often asked student for sentence drilling and repeating sentences after them in English. Inclusively, the findings of this study depicted that most English Teachers agreed that they describe grammar only when
\end{abstract}


required in class. The study suggests that English should be taught only by the teachers qualified in this subject. It is further suggested that speaking skill should be assessed in the board examination, only in that case the English teachers would focus teaching of speaking skill in their English classes in order to enhance communicative competence of their students.

\section{KEYWORDS}

Communicative competence, English language, Teaching, speaking skills, English

\section{INTRODUCTION}

An investigation about perception can play a vital role in getting a deeper insight regarding ones thinking. Before 1930s, several psychologists and theorists used to review elementary essentials of perception, but since then they have started to concentrate their review on complete psychological designs of perception (Démuth, 2013). According to Démuth (2013) philosophies that are most relevant of defining perception as a procedure, through which information is obtained and administered, can be separated into two elementary groups: The bottom-up theories of perception and the top-down indirect theories of perception.

Research related to the investigation of teachers' perception started towards the end of the 1970s and beginning of 1980s and quickly vast research started in this field (Clark \& Peterson, 1986; Kagan, 1992). Some researchers assumed that as thought controls the attitude, thus knowing the perceptions of teachers can play a vital role in understanding teachers' performances in classrooms and can deliver a guide for refining teachers' practices. Harb, Bakar \& Krish (2013) conducted a study at Jordanian universities in which they investigated teachers' and students' towards the use of technical aids in the process of instructing and learning oral skill in English language. Farooq (2015) in a study investigated perceptions of teachers and their practices concerning Communicative Language Teaching (CLT) and its effect on learner's communicative competence. Sarfraz, Mansoor, \& Tariq (2015) in a research analyzed the perceptions of teachers' and students' in the Computer Assisted Language Learning environment (CALL).

Speech is an important language skill used to give one's verbal production. Speech is the language skill that infants begin with after encountering listening. 
Halliday (1975) considers that babies start by acquiring what they listen and after that they naturally begin talking in the following years at school. Burns \& Joyce (1997) define Speaking skill as a communicating procedure of creating meaning that includes creating, receiving and treating information. Competence in speaking skill is indispensable for scholastic, individual, and professional achievement in a student's life (Osborn, Pearson, \& Morreale, 2000). Competency in speaking skill of English language ensures effective communication in this language and the danger is that speaking is taken for granted (Grugeon, Hubbard, Smith, \& Dawes, 2005). Speaking is the principal technique aimed for communication. Therefore, communicative competence is the most influential capability that the learner requires in developing oral skills (Nawab, 2012).

Teaching Speaking skill is of great importance in effective communication, despite this for many years, teaching speaking has been underrated and English language teachers have taken it for granted. Alonso (2013) believes that teaching speaking skill has not always been the main focus of interest in different language teaching methodologies, but has often been seen as a means of developing teaching methodologies. According to Brown \& Yule (1999) speaking proficiency involves the exact employment of vocabulary, impulsive evaluation of words and appropriateness of grammar. Wegerif, Mercer \& Dawes (1999) observed that in classroom, speaking enables children to cultivate an intelligence of lifetime's practices and to define the world. They believed that children individually and in collaboration with other children learn the usage of language as a tool for thinking, nevertheless language proficiency is impossible without guidance from the teachers.

Speaking activities can play a vital role in improving speaking skill of English as Second Language students. Kayi (2006) believes that Speaking can be encouraged using activities such as brainstorming, discussions, information gap, interviews, playing cards, etc. Smith (2005) lists several teaching strategies which specifically use speaking and listening as a curriculum focus. Dawes (2005) suggests that Computer based activities can also help Children to understand that spoken language aids the usage of talk to think collectively, and that such talk benefits both their individual improvement and their group work. According to Patil (2008) the issues of shyness and nervousness in speaking can be overcome by generating such occasions where students can use English in an expressive, suitable and genuine manner. 
In the context of Pakistan, English is the official language and the language of the elite class. Language policies of government give priority to English over other languages (Rahman, 2006). English as Second Language (ESL) learning in Pakistan is considered problematic both for learners and educators. There is a very high failure ratio in the subject of English as compared to other subjects (Tariq, Bilal, Sandhu, Iqbal, \& Hayat, 2013). Warsi (2004) in the context of Pakistan, considers that the circumstances under which English is taught in Pakistan are not helpful for educating and learning language. According to him it is certain that the strategies for instructing English dialect in Pakistan have not achieved its desired role of communicative competence. Shamim (2008) believes that in Pakistan it's generally assumed that, who so ever can speak English smoothly can also teach it. Conversely, the reality is quite different to it. In many cases, teachers themselves hardly know how to speak English, but are given the charge to teach it.

In Pakistan, the spoken English is not taught during teaching training courses, because the trainers do not consider it important that their use of English will help the student teachers in developing their communicative skills (Mahmood \& Ghani, 2012). The dilemma in Pakistani government schools, colleges and universities is that English speaking skill is not focused in syllabus. Therefore, students do not pay attention towards English speaking skill. Subsequently, the level of English-speaking capability is low in outgoing graduates of higher education in Pakistan (Alam M. , 2012).

Jabeen (2013) in a study investigated whether collaborative language learning will help the learners to improve their listening and speaking skills or not. Alam \& Uddin (2013) did an action research focused on improvement of Oral Communication Skills (OCSs) of Pakistan's Public school's Grade-6 students. Esmail, Ahmed, \& Noreen (2015) investigated factors and causes that makes Pakistani college and university students unable to communicate effectively in English as second language though they are studying English from primary level.

In the context of English as second language (ESL) teaching at Quetta. Manan et al (2015) found that a vast majority of stakeholders extend overwhelming attitude towards straight-for-English policy in education but, contrary to it Urdu was used as the medium of instruction and communication in real classroom 
practice. In a study Manan, Dumanig, \& David (2015) examined perceptions of shareholders and the actual rehearses of classroom, in order to categorize academic flaws and the challenges faced in teaching, in the schools that are low-fee. Researchers found that Grammar Translation Methodology (GTM) and the actual flawed classrooms practices hinders the development of competence in communication, origination of conception, and internalization of language in English language. Zeeshan (2016) in a study investigated attitudes of Quetta's government school students towards Grammar Translation Method (GTM) and Communicative Language Teaching (CLT). Findings revealed that generally, students showed encouraging attitudes towards Communicative Language Teaching (CLT) as compare to that, students showed either middle-of-the-road or a less encouraging attitude towards Grammar Translation Method (GTM).

Communicative Competence is the main theory in Communicative Language Teaching. Communicative competence came as a counter movement to linguistic competence given by Chomsky (1965). The expression communicative competence was presented in 1960s by Dell Hymes. Hymes (1972) associated his formation of communicative competence to the practical along with the theoretical needs. According to him performance is the evident part that is noticeable while competence is the incidental capability of producing the upcoming witnessed presentation. Hymes recommended that in communicative competence the sake of speaking and interacting in a language the acquaintance of grammatical rules alone is not sufficient (Rickheit, Strohner, \& Vorwerg, 2008). Communicative competence according to Canale and Swain (1980) is an amalgamation of an underlined organization of information and ability that is important for the sake of communication. Richards and Rodgers (1986) defined communicative competence as, the capability to practice the linguistic scheme efficiently and applicably. According to Paulston (1992) communicative competence simply means the practice of delicacy and decent behaviors while dealing with different people of society. Richards \& Schmidt (2010) define communicative competence as an understanding of knowing what is lawfully probable, appropriate, feasible, or practical in a particular language community. From Hymes till the date communicative competence has been defined in different ways but one thing found common is its emphasis on effective and comprehensible communication between speaker and listener in getting their message across. 
Competency in speaking skill of English language ensures effective communication in this language and the danger is that speaking is taken for granted (Grugeon, 2005). In the context of Pakistan, it's seen that students of government secondary school cannot properly communicate in English language. The teaching of speaking skill of the students by the teachers is not often conducted. As a result, most of the students of government schools are weak in oral communication (Jabeen A. , 2015; Alam M. , 2012; Alam \& Uddin, 2013; Mahmood \& Ghani, 2012; Tariq, 2013). This weakness in oral communication can be overcome after investigating teachers' perceptions about the speaking skill of their (Jabeen A. , 2015; Alam M. , 2012; Alam \& Uddin, 2013; Mahmood \& Ghani, 2012; students and the challenges they face in teaching speaking skill.

The aim of this study is to investigate perceptions of secondary school English teachers of Quetta regarding the challenges English teachers face in teaching speaking skills. Investigating government secondary school English teachers' perceptions about speaking skill will help to understand how they perceive this skill, which in result will help in overcoming the underlying identified challenges on the macro and micro level.

\section{LITERATURE REVIEW Perception}

Before 1930s, several psychologists and theorists used to review elementary essentials of perception but since then they start to concentrate their review on complete psychological designs of perception. The holists believed that reviewing this type of multifaceted substance as perception isn't possible simply through reviewing the single merits from the outside. For this very reason, psychologists and theorists started to review perception from inside, this was done by investigating the arrangements through which perception is structured (Démuth, 2013). According to Démuth (2013) defining perception as a procedure, can be separated into two elementary groups: The bottom-up direct theories of perception and The top-down indirect theories of perception. According to the bottom-up direct theorists, sensory input signifies the grounding of reasoning and naturally it regulates added processing of sensory data. So far the emphasis on nature of sensory input is According to the theories of top-down indirect perception, perception is possible only by means of mental representation, computation or creating a picture of a given reality (Démuth, 2013). According to McLeod Top down processing refers to the use of contextual information in pattern recognition. For e.g. difficult handwriting is understood if a complete sentence is read as compare to isolated words, because 
surrounding words aid understanding (McLeod, 2007). According to the way we arrive at this interpretation, we can divide the theories into constructivist, computational and synthesizing ones (Démuth, 2013).

\section{Perceptions of English as Second Language (ESL) Teachers}

English that has now acquired the status of an international language was originally the language spoken in England, with the historical struggles of the British Empire it has become the first or second language of many states which were previously colonies of British Empire. According to Richards and Schmidt (2010) English as a second language (ESL) is the second language of anyone who learns and speaks English language after learning their mother tongue. English has acquired the status of second language in the countries where it is learned in order to be used in day-to-day routine, for the educational purpose and for business.

Research related to the investigation of teachers perception started towards the end of 1970s and beginning of 1980s and quickly vast research started in this field (Clark \& Peterson, 1986; Kagan, 1992). Some researchers (Ashton, 1990; Brookhart \& Freeman, 1992; Clark, 1988) assumed that as thought controls the attitude, thus knowing the perceptions of teachers can play a vital role in understanding teachers' performances in classrooms and can deliver a guide for refining teachers' practices.

Harb et al. (2013) conducted a study at Jordanian universities in which they investigated teachers' and students' attitude towards the use of technical aids in the process of instructing and learning oral skill in English language. An amalgamation of optimistic and pessimistic feedback from the responses of respondents was revealed in the findings. Nonetheless the findings revealed the concern of respondents in smearing use of technical aid in the process of instructing and learning oral skills of English language at tertiary level.

Farooq (2015) in a study investigated perceptions of teachers and their practices concerning Communicative Language Teaching (CLT) and its effect on learner's communicative competence. Findings of this investigation showed that although teachers showed interest in implementing Communicative Language Teaching (CLT), but they were not accepting it totally because of the challenges and issues they could possibly face in its implementation such as, 
overloaded classrooms, low level of adeptness of students, time limitations, unavailability of audio-visual utilities, etc.

Sarfraz et al. (2015) in a research analyzed the perceptions of teachers' and students' in the Computer Assisted Language Learning environment (CALL). A positive attitude towards CALL was found overall in the teachers' and students' perceptions. Nevertheless, in their perceptions concerning the suitability of Computer Assisted Language Learning environment (CALL) some dissimilarity was also reported.

\section{Speaking skill}

Speech is an important language skill used to give one's verbal production. Speaking is the oral use of language to communicate with others. Speech is the language skill that infants begin with after encountering listening. Halliday (1975) considers that babies start by acquiring what they listen and after that they naturally begin talking in the following years at school. Burns \& Joyce (1997) define Speaking skill as a communicating procedure of creating meaning that includes creating, receiving and treating information. Its form and meaning are reliant on the situation in which it happens, the partakers, and the purposes of speaking. Competence in speaking skill is indispensable for scholastic, individual, and professional achievement in a students' life (Osborn, 2000). Harmer (2001) includes that talking happens when two individuals are occupied with conversing with each other and they are away from any doubt that they are doing it reasonably. Their reason might be that they need to state something, they have some open purposes, and they select from their language store. According to Nunan (2003) speech is the creative oral language skill that allows one to produce a spoken statement that is logical in order to express oneself meaningfully to get the message across. Competency in speaking skill of English language ensures effective communication in this language and the danger is that speaking is taken for granted. Speaking completes the basic requirement of a dialect for building up communal connection. Speaking is the principal technique aimed for communication. Therefore, communicative competence is the most influential capability that the learner requires in developing oral skills (Nawab, 2012).

\section{Teaching English Speaking Skill}

Languages are commonly taught using four skills namely: listening, speaking, reading, and writing. Teaching Speaking skill is of great importance in effective 
communication, despite this for many years, teaching speaking has been underrated and English language teachers have taken it for granted. Alonso (2013) believes that teaching speaking skill has not always been the main focus of interest in different language teaching methodologies, but has often been seen as a means of developing teaching methodologies. According to him, teaching the speaking skill has commonly not been a righteous objective. According to Brown \& Yule (1999) as indicated by the normal way to language acquisition, talking is the following dialect aptitude after Listening. The speaking proficiency involves the exact employment of vocabulary, impulsive evaluation of words and appropriateness of grammar. Additionally, Speaking also focuses the importance of correct pronunciation and intonation. Overcoming these challenges is challenging for both instructors and learners. Wegerif, (1999) observed that in classroom, speaking enables children to cultivate an intelligence of lifetime's practices and to define the world. They believed that children individually and in collaboration with other children learn the usage of language as a tool for thinking, nevertheless language proficiency is impossible without guidance from the teachers. This shows that for language proficiency, teaching, speaking skill and involves students in speaking activities is very important.

\section{Role of speaking activities in promoting speaking skill of students}

Speaking activities can play a vital role in improving speaking skill of English as Second Language students. Kayi (2006) believes that Speaking can be encouraged using activities such as brain storming, discussions, information gap, interviews, playing cards, picture describing, picture narrating role plays, reporting simulation, storytelling, story completion and finding the difference. Smith (2005) lists several teaching strategies which specifically use speaking and listening as a curriculum focus, these are Teacher-directed discussion/whole-class teaching, Talk partners, Developing listening skills, Brainstorming, Review times: Plenaries, pit stops and in-flight checks, Hot seating, Visits, visiting speakers and listeners, Reading inside and outside the Literacy Hour, Circle time. Dawes (2005) suggests that Computer based activities can also help Children to understand that spoken language aids the usage of talk to think collectively, and that such talk benefits both their individual improvement and their group work. Computer based activities offer an outstanding chance to rehearsal thinking and talking that can be beneficial for them in different spheres of life, for this very reason children have a strong motivation towards the use of computer-based activities. Computer based talk 
activities are Disputation talk, Cumulative talk, Exploratory talk. According to Patil (2008) the issues of shyness and nervousness in speaking can be overcome by generating such occasions where students can use English in an expressive, suitable and genuine manner. He believes that learners love to play with language and gradually they develop a sense of confidence towards the use of language. According to him soon as learners resolve the issues of anxiety, they start using English artistically. They attempt to use as much language as possible as they are not afraid of making mistakes, and in due course of time they grab more vocabulary and structures.

\section{Scenario of Teaching English as Second Language (ESL) in Pakistan}

Kachru (1985) splits English speakers into three groups in his "Threecircle Model of World Englishers": "inner circle", "outer circle" and "expanding circle" (Jenkins, 2003, p. 10). Pakistan according to this division stands in outer circle where English is used as a second language in the fields of education, administration, and business (Jenkins, 2003). In the context of Pakistan, English is the official language and the language of the elite class. Language policies of government gives priority to English over other languages (Rahman, Language policy, multilingualism and language vitality in Pakistan, 2006).

English as Second Language (ESL) learning in Pakistan is considered problematic both for learners and educators. There is a very high failure ratio in the subject of English as compared to other subjects (Tariq, 2013). Shamim (2008) believes that in Pakistan it's generally assumed that, who so ever can speak English smoothly can also teach it. Conversely, the reality is quite different to it. In many cases, teachers themselves hardly know how to speak English, but are given the charge to teach it. This is so for the reason that in many situations teaching English is connected to translation of English into mother tongue, which is usually Urdu. Malik (2008) conducted a study in Karachi, which tried to investigate the question: Who are the teachers of English? The study searched the backgrounds and qualification of English teachers teaching English in both private and public sectors. It was found that $36 \%$ teachers had Master's in subjects other than English such as Islamic Studies, Urdu and Economics. 18\% teachers were Science graduates, while the remaining $82 \%$ teachers had graduated in Social Sciences or Humanities. Warsi (2004) in the context of Pakistan, considers that the circumstances under which English is taught in Pakistan are not helpful for educating and learning 
language. According to him it is certain that the strategies for instructing English dialect in Pakistan have not achieved its desired role of communicative competence. In Pakistan English is taught using grammar translation method which pays no attention to listening and speaking.

\section{Scenario of Teaching English Speaking Skill in Pakistan}

In Pakistan, the spoken English is not taught during teaching training courses, because the trainers do not consider it important that their use of English will help the student teachers in developing their communicative skills (Mahmood $\&$ Ghani, 2012). The dilemma in Pakistani government schools, colleges and universities is that English speaking skill is not focused in syllabus. Therefore, students do not pay attention towards English speaking skill. Subsequently, the level of English-speaking capability is low in outgoing graduates of higher education in Pakistan (Alam M. , 2012). Jabeen (2013) in a study investigated whether collaborative language learning will help the learners to improve their listening and speaking skills or not. Through an experimental research it was found that the participants of experimental study demonstrated better understanding of the ideas, messages and information offered in English and performed better in speaking skill tasks. Alam \& Uddin (2013) did an action research focused on improvement of Oral Communication Skills (OCSs) of Pakistan's Public school's Grade-6 students. Findings of Pre and post intervention phases of four participants revealed that providing a favorable learning environment and using new teaching strategies helps in improving children's Oral Communication Skills (OCSs). Esmail, Ahmed, \& Noreen (2015) investigated factors and causes that makes Pakistani college and university students unable to communicate effectively in English as second language, though they are studying English from primary level. The findings revealed that mostly students were preys of problems i.e. "lack of vocabulary, syntax, fluency, cramming, and poor understanding of grammatical rules, proper use of tenses and structure of a sentence and hesitation in pronunciation".

\section{Scenario of English as Second Language (ESL) teaching in Quetta, Baluchistan}

Quetta the capital of Balochistan, Pakistan is situated near to the boundaries of Afghanistan and Iran. Quetta is a city where people speaking different language live (Manan, Dumanig, \& David, 2015). According to a survey conducted by Naqeebullah (2013) in Quetta city there were overall 471 Government schools 
while the number of private schools that were low-fee numbered around 664 . In the context of English as second language (ESL) teaching at Quetta. Manan et al (2015) found that a vast majority of stakeholders extend overwhelming attitude towards straight-for-English policy in education but, contrary to it Urdu was used as the medium of instruction and communication in real classroom practice. In a study Manan, Dumanig, \& David (2015) examined perceptions of shareholders and the actual rehearses of classroom, in order to categorize academic flaws and the challenges faced in teaching, in the schools that are low-fee. Findings of this study revealed that most of the respondents perceived early-English policy unavoidable. However, it was found that actual English teaching practices were contrary to the perceptions as rarely English is used in classroom communication while Urdu is mostly used. Researchers found that Grammar Translation Methodology (GTM) and the actual flawed classrooms practices hinders the development of competence in communication, origination of conception and internalization of language in English language. Manan, David, \& Dumanig (2016) conducted a research in the private Englishmedium schools in Quetta. They researched application and discourse of the experts of schools about dialects that are native and phonetic differences, and their possible impacts on students' impression. The review utilized Foucault's theoretical framework of governmentality. The study employed a blended technique that utilized students of high level, educators and school principals. Discoveries revealed that school specialists practice stringent systems, for example, notices, wall paintings, punishments in order to defeat the utilization of native languages. Zeeshan (2016) in a study investigated attitudes of Quetta's government school students towards Grammar Translation Method (GTM) and Communicative Language Teaching (CLT). Findings revealed that generally, students showed encouraging attitudes towards Communicative Language Teaching (CLT) as compare to that, students showed either middle-of-the-road or a less encouraging attitude towards Grammar Translation Method (GTM). The researcher suggested that policy makers should consider the use of adapted or adopted method of communicative Language Teaching (CLT) aimed to teach English effectively in the secondary government schools of Quetta.

\section{Communicative Competence}

The language learning process and its development is explained by several intellects in their approaches and theories. These theories are the result of profound works and toil of years and experience, and intend to explain the acquisition, the learning, the development at various levels towards tutoring 
and learning a certain language as first, second or other grade assigned to it, according to the usage and necessity in life and interaction. Among such theories, communicative competence theory is one. Communicative Competence is the main theory in Communicative Language Teaching. Communicative competence came as a counter movement to linguistic competence given by Chomsky (1965) according to whom linguistic concept is based on a perfect speaker-listener linguistic association that is not affected by cognition and situation during linguistic presentation. The expression communicative competence was presented in 1960s by Dell Hymes., Hymes (1972) associated his formation of communicative competence to the practical along with the theoretical needs. In his view these two notions are like two sides of a coin. According to him performance is the evident part that is noticeable while competence is the incidental capability of producing the upcoming witnessed presentation. Hymes recommended that in communicative competence the sake of speaking and interacting in a language the acquaintance of grammatical rules alone is not sufficient (Rickheit, Strohner, \& Vorwerg, 2008). Hymes (1972) projected that for a complete education of language and communication the following four inquiries should be made:

1. Whether (and to what degree) something is formally possible;

2. Whether (and to what degree) something is feasible;

3. Whether (and to what degree) something is appropriate;

4. Whether (and to which degree) something is done (Hymes, 1972, pp. 284286).

Communicative competence according to Canale and Swain (1980) is an amalgamation of an underlined organization of information and ability that is important for the sake of communication. In this indication of communicative competence, information means a person's conscious or unconscious learning of a language and different parts of language utilization. Spitzberg and Cupach (1984) debated that: "competence as a trait ultimately must boil down to an individual effectively communicating across contexts with different environments, with diverse goals and topics. This consistency of performance is really tantamount to general communicative adaptability and behavioral flexibility" (Spitzberg \& Cupach, 1984, p. 92). Richards and Rodgers (1986) defined communicative competence as, the capability to practice the linguistic scheme efficiently and applicably. According to Paulston (1992) communicative competence simply means the practice of delicacy and decent behaviors while dealing with different people of society. According to him we 
do our students a damage if we don't demonstrate to them the social directions along with the linguistic directions. Richards \& Schmidt (2010) define communicative competence as an understanding of knowing what is lawfully probable, appropriate, feasible, or practical in a particular language community. From Hymes till the date communicative competence has been defined in different ways but one thing found common is its emphasis on effective and comprehensible communication between speaker and listener in getting their message across.

\section{OBJECTIVE}

1. To investigate secondary school English teachers' perceptions regarding the challenges they face in teaching English speaking skills to their students.

\section{RESEARCH METHODOLOGY}

Communicative Competence was used as a theoretical framework to supplement this study. Overall Communicative competence has four aspects such as: Grammatical competence, Sociolinguistic competence, Discourse competence and Strategic competence (Richards \& Schmidt, 2010). The aspect of Communicative competence used in this study is Discourse competence. It is concerned with the selection of words, sequencing, association of words, courses of action, sentences and proclamations in order to accomplish a unified talked or composed content. There are many other elements which aid Discourse competence for example, cohesion, intelligibility, deixis, bland structure, and the natural conversational structure (Celce-Murcia, Dörnyei, and Thurrell, 1995). This study employed a Quantitative design of survey research to know the teachers' perceptions. In quantitative research, according to Creswell (2011) the researcher tries to find a research problem centered on tendencies present in that particular area, or in order to describe the reason behind the occurring of something. The study took about 3-4 months in collecting data from 100 male and female Government Secondary School English teachers.

Participants of this study were from 16 Girls and Boys High schools of Quetta city. 100 Government Secondary School English teachers participated in this study, out of them 50 were female while 50 were male secondary school teachers. Data from the participants was collected through questionnaires. The questionnaire used in this study was adapted from a questionnaire designed by Perez-Gore et al. (2011) who had adapted from Savignon \& Wang (2003) aimed 
to investigate teacher and student perceptions about Communicative Language Teaching (CLT) practices.

\section{DATA ANALYSIS}

The data obtained from questionnaire was entered into Statistical Package for the Social Sciences (SPSS). Mean, standard deviation and frequency were computed using SPSS.

Objective: To investigate secondary school English teachers' perceptions regarding the challenges they face in Teaching speaking skills English to their students.

Descriptive statistics for this objective was calculated using SPSS, in order to find Mean, Standard Deviation, Frequency and Valid Percent of English teachers' perceptions regarding the challenges they face in teaching speaking skills to their students.

As shown in Table 1 teachers' attitude towards teaching practice of students speaking skill items $(1-10)$ mean rating ranged from lowest rating of 3.20 for the item pointing that students rarely talk in English in the classroom, to the highest rating of 4.10 for the item pointing that teachers frequently correct their students' mistakes committed during speaking in classroom. Standard deviation for this part of questionnaire items ranged from 1.070 to 1.425.

\section{Table. 1}

Mean Rating and Standard Deviation for the questionnaire Part 1

\begin{tabular}{llc}
\hline $\begin{array}{l}\text { English language Teaching practice of students } \\
\text { Speaking skill }\end{array}$ & Mean & $\begin{array}{c}\text { Std. } \\
\text { Devia } \\
\text { tion }\end{array}$ \\
\hline $\begin{array}{l}\text { 1. I mostly describe grammatical rules and students } \\
\text { learn them orally. }\end{array}$ & 3.48 & 1.425 \\
$\begin{array}{l}\text { 2. In the classroom I usually use Urdu with my } \\
\quad \begin{array}{l}\text { understudies. } \\
\text { 3. I frequently ask students for drilling and repeating }\end{array}\end{array}$ & 4.28 & 1.102 \\
$\begin{array}{l}\text { sentences. } \\
\text { In the classroom my understudies once in a while }\end{array}$ & 3.20 & 1.119 \\
$\quad$ interact in English. & &
\end{tabular}


5. I regularly plan activities that involve students to communicate in English with one another.

6. I sometimes give students a chance to sing and play in English in classroom.

7. I focus communication in my English classes; however I describe grammar when required.

8. I frequently correct errors of my students in speaking in classroom.

9. I feel undisturbed demonstrating English for my understudies to revise.

10. I feel confident when I Correct my students' mistakes while speaking in English

As shown in Table 2 below, teachers' attitude towards teaching practice of students Speaking skill items $(1-10), 33$ out of 100 English teachers strongly agreed that they describe grammatical rules and students learn them orally, 29 out of 100 teachers had neutral response to the item "In the classroom I usually use Urdu with my understudies"; Majority of 43 out of 100 teachers strongly agreed to the item "I frequently ask students for drilling and repeating sentences"; 31 out of 100 teachers were neutral about the item "In the classroom my understudies once in a while interact in English"; 38 out of 100 teachers agreed to the item "I regularly plan activities that involve students to communicate in English with one another"; 33 out of 100 teachers agreed to the item "I sometimes give students a chance to sing and play in English in classroom"; 36 out of 100 teachers agreed to the item "I focus communication in my English classes, however I describe grammar when required."; 54 out of 100 teachers strongly agreed to the item "I frequently correct errors of my students in speaking in classroom."; 43 out of 100 teachers strongly agreed to the item "I feel undisturbed demonstrating English for my understudies to revise"; 44 out of 100 teachers strongly agreed to the item "I feel confident when I Correct my students' mistakes while speaking in English”.

Table 2

Frequency and Valid percent for questionnaire part 1

\begin{tabular}{l|c|c|c}
\hline $\begin{array}{l}\text { My English language Teaching } \\
\text { practice of students Speaking skill }\end{array}$ & $\begin{array}{c}\text { Likert } \\
\text { Scale }\end{array}$ & Frequency & $\begin{array}{c}\text { Valid } \\
\text { Percent }\end{array}$ \\
\hline
\end{tabular}


Pakistan Journal of Educational Research, Vol 1, Issue 1 (2018)

Teaching of English.

1. I mostly describe grammatical rules and students learn them orally.

\begin{tabular}{|c|c|c|}
\hline $\begin{array}{l}\text { strongly } \\
\text { disagree }\end{array}$ & 14 & 14.0 \\
\hline Disagree & 13 & 13.0 \\
\hline Neutral & 17 & 17.0 \\
\hline Agree & 23 & 23.0 \\
\hline $\begin{array}{c}\text { strongly } \\
\text { agree }\end{array}$ & 33 & 33.0 \\
\hline $\begin{array}{l}\text { strongly } \\
\text { disagree }\end{array}$ & 3 & 3.0 \\
\hline disagree & 25 & 25.0 \\
\hline neutral & 29 & 29.0 \\
\hline agree & 27 & 27.0 \\
\hline $\begin{array}{l}\text { strongly } \\
\text { agree }\end{array}$ & 16 & 16.0 \\
\hline $\begin{array}{l}\text { strongly } \\
\text { disagree }\end{array}$ & 1 & 1.0 \\
\hline disagree & 16 & 16.0 \\
\hline neutral & 8 & 8.0 \\
\hline agree & 32 & 32.0 \\
\hline $\begin{array}{l}\text { strongly } \\
\text { agree }\end{array}$ & 43 & 43.0 \\
\hline $\begin{array}{l}\text { strongly } \\
\text { disagree }\end{array}$ & 15 & 15.0 \\
\hline disagree & 11 & 11.0 \\
\hline neutral & 31 & 31.0 \\
\hline agree & 25 & 25.0 \\
\hline $\begin{array}{c}\text { strongly } \\
\text { agree }\end{array}$ & 18 & 18.0 \\
\hline $\begin{array}{l}\text { strongly } \\
\text { disagree }\end{array}$ & 7 & 7.0 \\
\hline disagree & 16 & 16.0 \\
\hline neutral & 10 & 10.0 \\
\hline agree & 38 & 38.0 \\
\hline $\begin{array}{l}\text { strongly } \\
\text { agree }\end{array}$ & 29 & 29.0 \\
\hline $\begin{array}{l}\text { strongly } \\
\text { disagree }\end{array}$ & 14 & 14.0 \\
\hline
\end{tabular}

2. In the classroom I usually use Urdu with my understudies.

3. I frequently ask students for drilling and repeating sentences.

4. In the classroom my understudies once in a while interact in English.

5. I regularly plan activities that involve students to communicate in English with one another. 
6. I sometimes give students a chance to sing and play in English in classroom

7. I focus communication in my English classes, however I describe grammar when required.

8. I frequently correct errors of my students in speaking in classroom.

9. I feel undisturbed demonstrating English for my understudies to revise.

10. I feel confident when I Correct my students' mistakes while speaking in English.

\begin{tabular}{|c|c|c|}
\hline disagree & 20 & 20.0 \\
\hline neutral & 8 & 8.0 \\
\hline agree & 33 & 33.0 \\
\hline $\begin{array}{c}\text { strongly } \\
\text { agree }\end{array}$ & 25 & 25.0 \\
\hline $\begin{array}{l}\text { strongly } \\
\text { disagree }\end{array}$ & 4 & 4.0 \\
\hline disagree & 7 & 7.0 \\
\hline neutral & 23 & 23.0 \\
\hline agree & 36 & 36.0 \\
\hline $\begin{array}{l}\text { strongly } \\
\text { agree }\end{array}$ & 30 & 30.0 \\
\hline $\begin{array}{l}\text { strongly } \\
\text { disagree }\end{array}$ & 7 & 7.0 \\
\hline disagree & 6 & 6.0 \\
\hline neutral & 11 & 11.0 \\
\hline agree & 22 & 22.0 \\
\hline $\begin{array}{c}\text { strongly } \\
\text { agree }\end{array}$ & 54 & 54.0 \\
\hline $\begin{array}{l}\text { strongly } \\
\text { disagree }\end{array}$ & 6 & 6.0 \\
\hline disagree & 9 & 9.0 \\
\hline neutral & 14 & 14.0 \\
\hline agree & 28 & 28.0 \\
\hline $\begin{array}{c}\text { strongly } \\
\text { agree }\end{array}$ & 43 & 43.0 \\
\hline $\begin{array}{l}\text { strongly } \\
\text { disagree }\end{array}$ & 6 & 6.0 \\
\hline disagree & 10 & 10.0 \\
\hline neutral & 12 & 12.0 \\
\hline agree & 28 & 28.0 \\
\hline $\begin{array}{l}\text { strongly } \\
\text { agree }\end{array}$ & 44 & 44.0 \\
\hline
\end{tabular}




\section{FINDINGS, DISCUSSION AND RECOMMENDATIONS}

Overall, findings in relation to English teachers' perceptions regarding the challenges they face in teaching speaking skill revealed that majority of teachers had a neutral response towards the use of Urdu or English in class by their students and by themselves. Majority of English teachers strongly agreed that they often ask their students for sentence drilling, repeating in English. It revealed that behavioristic approach of language teaching is most common as students are asked for repetition and sentence drilling (Lightbown \& Spada, 2006). Inclusively, majority of English teachers strongly agreed that they feel undisturbed demonstrating English for my understudies to revise. It was found that teachers had a positive response towards designing activities that require students to interact with each other in English, and they sometimes have students play and sing in the English lesson. Finding concerning focus on explanation of grammar rules or focus on communication was somehow contradictory as teachers had equally positive response towards both of them. Findings concerning correcting students' mistakes revealed that teachers had highly positive response towards it, additionally they perceived that they felt confident doing so.

Conclusively, the main purpose of this study was to investigate the Perceptions of male and female Government Secondary School English Teachers' of Quetta about Teaching English Speaking Skill of their students'. After visiting different girls' and boys' secondary schools of Quetta, it was found that English in secondary schools of Quetta is taught by Secondary School Teacher (General) who were specialized in other subjects than English, such as: History, Philosophy, Statistics, Economics, Islamiat, Urdu, Political Science, Civics etc. Unfortunately, they had not received any teacher training in general or in English language teaching in particular. While interacting with teachers Few of English teachers frankly reported that their main goal while teaching English in secondary classes is not to enhance communication skill of student, but to complete the syllabus which hinders opportunities of practicing teaching of speaking skill. A teacher said that communication cannot be our goal of teaching English in secondary classes and we do not focus on teaching speaking skill, for the reason that, in board examination students speaking skill is not assessed.

Dilemma with teaching of English language in Public schools of Pakistan is that majority of teachers are not qualified in this subject, they are forced to teach 
English without taking into consideration their educational background. To the best of researchers' knowledge teaching a subject in which one is specialized can be more effective. As such teacher would be more confident and motivated. Such teacher would have more knowledge about the particular subject helshe is qualified in, which in return can ensure effective teaching of that particular subject. Additionally, main goal of secondary school English teachers is to complete the syllabus and to prepare the students for examination, according to the need of that examination. As speaking skill is not assessed in exams, thus it's totally neglected by the English teachers. A possible solution to it is that speaking skill should also be assessed in examination, so that teachers focus teaching of speaking skill. Furthermore, lack of teachers training program specially related to English language teaching also hinders effective teaching of this subject in order to achieve communicative competence. To resolve this issue teachers training program specially related to English language teaching should be held regularly.

This study investigated the perception of secondary school male and female teachers' teaching of speaking skill of their students. In future parallel studies can be focused at the intermediate, graduate, and tertiary levels in Quetta and other cities of Balochistan. The focus in this study was on investigating the perceptions of English teachers towards speaking skill a similar study can be conducted in future focusing writing, reading and listening skills of students.

\section{REFERENCES}

Alam, M. (2012). Assessment of Oral Skills Development among the Students of Master in Education in the Public Sector. Sarghoda: University of Sarghoda.

Alam, Q., \& Uddin, A. B. (2013). Improving English Oral Communication Skills of Pakistani Public School's Students . International Journal of English Language Teaching, 1(2), 17-36.

Alonso, R. A. (2013). Teaching Speaking: An Exploratory Study in Two Academic Contexts. Porta Linguarum, 22, 145-160.

Ashton, P. T. (1990). Editorial. Journal of Teacher Education, 42(1), 2.

Begum, A. D. (2002). Measuring socio-economic. In A. D. Begum, Measuring socioeconomic gender inequality in: Towards an alternative to the UNDP genderrelated development index. (p. 251: 30.). The Hague: Instt. of Social Studies.

Brookhart, B. A., \& Freeman, D. J. (1992). Characteristics of entering teacher candidates. Review of Educational Research, 62(1), 37-60. 
Brown, G., \& Yule, G. (1999). Teaching the Spoken Language. Cambridge : Cambridge University Press.

Burns, A., \& Joyce, H. (1997). Focus on Speaking. Sydney: National center for English Language Teaching and Research.

Canale, M., \& Swain, M. (1980). Theoretical Bases of Communicative Approaches to Second Language Teaching and Testing. Applied Linguistics, 1- 47.

Chomsky, N. (1965). Aspects of the Theory of Syntax. MIT Press.

Clark, C. M. (1988). Asking the right questions about teacher preparation: Contributions of research on teaching thinking. Educational Researcher, $17(2), 5-12$.

Clark, C., \& Peterson, P. (1986). Teachers' thought processes. In M. Wiltrock, Handbook of Research on Teaching (3rd ed., pp. 255-296.). New York: Macmillan.

Clark, S. C. ( (2000).). Work/family border theory: A new theory of work/family balance. Human Relations,53, , 747-770.

Creswell, J. W. (2011). Educational Research planning, conducting, and evaluating quantitative and qualitative research. Pearson.

Dawes, L. (2005). Speaking, Listening and Thinking with Computers. In E. Grugeon, L. Dawes, C. Smith, \& L. Hubbard, Teaching Speaking \& Listening in the Primary School. David Fulton.

De Souza, C. (1963). "The call of working Mother. Social Action, ",, 640-646.

Démuth, A. (2013). Perception Theories. Trnava.: Faculty of Philosophy.

Desai, V. (1967). Social Aspects of Savings, . Bombay: : Popular Prctka;han.

Diener, E. S. ((1999). Subjective well-being: Three decades of progress. . Psychological Bulletin, , 125, 276-302.

Esmail, A., Ahmed, M., \& Noreen, S. (2015). Why Do Pakistani Students are Reluctant to Speak English. Academic Research International, 6(3), 372383.

Farooq, M. U. (2015). Creating a Communicative Language Teaching Environment for Improving Students' Communicative Competence at EFL/EAP University Level. International Education Studies, 8(4), 179-191.

Francis, J. J. (2004). Constructing Questionnaires Based On The Theory Of Planned Behaviour A Manual For Health Services Researchers. . University Of Newcastle,C.

Frone, M. R. ((1992) ). 'Antecedents and outcomes of work-family conflict: Testing a model of work-family interface'.. Journal of Applied Psychology, 77 (1), : 65-78.

Greenhaus, J. H. ( (1985)). 'Sources of conflict between work and family roles'. Academy of Management Review, 10 (1): , 76-88.

Grugeon, E., Hubbard, L., Smith, C., \& Dawes, L. (2005). Teaching Speaking and Listening in the Primary School. Routledge. 
Guest, D. ). ((2002). 'Perspectives on the study of work-life balance',.. Social ScienceInformation, 41(2), 255-79.

Halliday. (1975). Learning how to mean . Oxford University press.

Harb, J., Bakar, N. A., \& Krish, P. (2013). Instructors' and Students' Perceptions Towards using Technology in Teaching and Learning Listening and Speaking at Jordanian Universities. Interdisciplinary Journal of Contemporary Research in Business, 4(9), 1027-1041.

Harmer, J. (2001). The Practice of English Language Teaching. Edinburgh: Pearson Education limited.

Hochschild, A. ,. (1997). The Time Bind: When Work Becomes Home and Home Becomes Work. New York:: Metropolitan Books.

Hom, P.W., and Kinicki, A.J.,. (2001). "Toward a greater understanding of how dissatisfaction drives, employee turnover",. The Academy of Management Journal, Volume No.44(5),,, pp.975- 987.

Hymes, D. (1972). On communicative competence. In J. B. Pride, \& J. Holmes, Sociolinguistics: selected readings (pp. 269-293). Harmondsworth: Penguin.

Jabeen, A. (2015). The Role of Error Analysis in Teaching and Learning of Second and Foreign Language. Education and Linguistics Research, 1(2), 52-61.

Jabeen, I. (2013). English Language Teaching Implementing Collaborative Language Learning ApproachIn Federal Colleges of Pakistan. (Pakistan Research Repository) Retrieved from Pakistan Research Repository.

Jenkins, J. (2003). World Englishes. Routledge.

Kachru, B. B. (1985). Standards, codification, and sociolinguistic realism: The English language in the outer circle. In R. Quirk, \& ELG.Widdowson (Eds.), English in the World: Teaching and Learning the language and the literature (pp. 11-30). Cambridge : Cambridge University Press.

Kagan, D. (1992). Implications of research on teacher beliefs. Educational Psychologist, 27(1), 65-90.

Kayi, H. (2006, November). Teaching Speaking: Activities to Promote Speaking in a Second Language. The Internet TESL Journal. Retrieved from The Internet TESL Journal

Kirchmeyer, C. .. ((2000)). In C. \&. (Eds.), Work-life initiatives: (pp. pp. 79-93).). West Sussex,UK: Wiley: ,Trends in organizational behavior.

Kofodimos, J. R. ((1993). Balancing act. . San Francisco: : Jossey-Bass.

Lightbown, P. M., \& Spada, N. (2006). How languages are learned (3rd ed.). Oxford University Press.

Mahmood, A., \& Ghani, M. (2012). Communicative Skills of Student Teachers in Pakistan. International Journal of Research in Linguistics and Social \& Applied Sciences, 1, 74-89. 
Malik, Z. A. (2008). Discovering identities of teachers of English in Pakistan. Discovering identities of teachers of English in Pakistan. Aga Khan University, Karachi, Pakistan.

Manan, S. A., David, M. K., \& Dumanig, F. P. (2016). Language management: a snapshot of governmentality within the private schools in Quetta, Pakistan. Language policy, 15(1), 3-26.

Manan, S. A., Dumanig, F. P., \& David, M. K. (2015). The English-medium fever in Pakistan: analyzing policy,perceptions and practices through additive bi/multilingual education lens. International Journal of Bilingual Education and Bilingualism, 1-17.

Mani, v. (2013). Work Life Balance and Women Professionals. Global Journal of Managemen tand Business Research Interdisciplinary ; 13(5.

Mark Tausig and RudyFenwic. (2001). "Unbinding Time: Alternate Work Schedules Work-Life Balance". , Journal of Family and Economic Issues, Volume No.22(2), Human Sciences Press, ,, pp.101-119.

McLeod, S. (2007). Visual Perception Theory. Retrieved from SImply Psychology: www.simplypsychology.org/perception-theories.html

Nawab, A. (2012). Is it the way to teach language the way we teach language? English language teaching in rural Pakistan. Academic Research International, 2(2), 696-705.

Neetu, 1. ((2009)). Social Justice \& Empowerment.

Netemeyer, R. B. ( (1996) ). 'Ddevelopment and validation of work - family conflict and family - work conflict scales'. . Journal of Applied Psychology, 81(4)., : 400-410.

Nunan, D. (2003). Practical English Language Teaching. McGraw-Hill Education.

Nye, F.I.Hoffman,L.W. (1963). "the employed Women in America". Chigago: Rand Mcmally and comoany.

Osborn, M. M., Pearson, J. C., \& Morreale, S. P. (2000). Why Communication is Important: A Rationale for the Centrality of the Study of Communication. Journal of the Association for Communication Administration, 29(1), 1-25.

Patil, Z. N. (2008). Rethinking the Objectives of Teaching English in Asia. Asian EFL Journal, 10(4), 227-240.

Paulston, C. B. (1992). Linguistic and Communicative Competence: Topics in ESL. Multilingual Matters.

Perez-Gore, I., McCormick, R., Burton, S., \& Siddique, M. A. (2011). Perceptions of English Language Learning and Teaching Among Primary and Secondary School Teachers and Students Participating in English in Action. Dhaka, Bangladesh: English in Action (EIA).

Perlow.L.A. (1995). Putting the work back into work/family. Group and Organization Management, ,, 20(2): 227-39. 
Pietromonaco, Paula.R. (1986). " Psychological consequences of Multilpe social Roles.". psychology of Women Quarterly, vol 10.

Polit, D. F., \&. Hungler, B. P. ((1999).). Nursing Research: Principles and Method. . Lippincott( 6 ed.).

Pramanik, R. (2011). Information and Communication Technology (ICT) among School-going Children.

Rahman, T. (2006). Language policy, multilingualism and language vitality in Pakistan. Trends in Liguistics Studies and Monographs, 175, 73-106.

Richards, J. C., \& Rodgers, T. S. (1986). Approaches and Methods in Language Teaching. Cambridge University Press.

Richards, J. C., \& Schmidt, R. (2010). Longman Dictionary of Language Teaching and Applied Linguistics. pearson.

Rickheit, G., Strohner, H., \& Vorwerg, C. (2008). The concept of communicative competence. In G. Rickheit, \& H. Strohner, Handbook of Communication Competence :Volume 1 of Handbooks of applied linguistics (pp. 15-62). Walter de Gruyter.

Sarfraz, S., Mansoor, Z., \& Tariq, R. (2015). Teachers' and students' perceptions of the communicative language teaching methodology in the CALL environment: A case study. Procedia - Social and Behavioral Sciences, 199, 730-736.

Savignon, S. J., \& Wang, C. (2003). Communicative language teaching in EFL contexts:Learner attitudes and perceptions. IRAL, 223-249.

Seth, M. .. (1995). Women's Development: Indian Initiatives. KURUKSHETRA-NEW DELHI-, , 43, 33-35.

Shamim, F. (2008). Trends, issues and challenges in English language education in Pakistan. Asia Pacific Journal of Education, 235-249.

Singh, K. (1972). " career and family .women's two roles.". Indian journal of social work ,Bombay.

Sinha, P. (1976). "Role conflict among Working Women,". New Delhi: Janaki Prakashan.

Smith, C. (2005). Developing Children's Oral Skills at Key Stage 2. In E. Grugeon, L. Dawes, C. Smith, \& L. Hubbard, Teaching Speaking \& Listening in the Primary School. David Fulton Publishers Ltd.

Spitzberg, B. H., \& Cupach, W. R. (1984). Interpersonal Communication Competence. SAGE Publications.

Tariq, A. R., Bilal, H. A., Sandhu, M. A., Iqbal, A., \& Hayat, U. (2013). Difficulties in Learning ENglish as a Second Language in Rural Areas of Pakistan. Academic Research International, 4(6).

Warsi, J. (2004). Conditions under which English is taught in Pakistan : an applied linguistic perspective. SARID Journal, 1(1), 1-9. 
Pakistan Journal of Educational Research, Vol 1, Issue 1 (2018) Teaching of English.

Wegerif, R., Mercer, N., \& Dawes, L. (1999, Febuary). Children's Talk and the Development of Reasoning in the Classroom. British Educational Research Journal.

Zeeshan, M. (2016). Pakistani Government Secondary Schools Students' Attitudes towards Communicative Language Teaching and Grammar Translation in Quetta, Balochistan. English Language Teaching, 9(3), 258-270. 